\title{
How IT-Enabled Dynamic Capabilities Add Value to the Development of Innovation Capabilities
}

Citation for published version (APA):

van de Wetering, R., \& Maaike, B. (2021). How IT-Enabled Dynamic Capabilities Add Value to the Development of Innovation Capabilities. In D. B. A. Mehdi Khosrow-Pour (Ed.), Encyclopedia of Organizational Knowledge, Administration, and Technology (pp. 999-1016). IGI Global. https://doi.org/10.4018/978-1-7998-3473-1.ch070

DOI:

10.4018/978-1-7998-3473-1.ch070

Document status and date:

Published: 01/02/2021

Document Version:

Peer reviewed version

Document license:

Taverne

Please check the document version of this publication:

- A submitted manuscript is the version of the article upon submission and before peer-review. There can be important differences between the submitted version and the official published version of record. People interested in the research are advised to contact the author for the final version of the publication, or visit the DOI to the publisher's website.

- The final author version and the galley proof are versions of the publication after peer review.

- The final published version features the final layout of the paper including the volume, issue and page numbers.

Link to publication

\section{General rights}

Copyright and moral rights for the publications made accessible in the public portal are retained by the authors and/or other copyright owners and it is a condition of accessing publications that users recognise and abide by the legal requirements associated with these rights.

- Users may download and print one copy of any publication from the public portal for the purpose of private study or research.

- You may not further distribute the material or use it for any profit-making activity or commercial gain

- You may freely distribute the URL identifying the publication in the public portal.

If the publication is distributed under the terms of Article 25fa of the Dutch Copyright Act, indicated by the "Taverne" license above, please follow below link for the End User Agreement:

https://www.ou.nl/taverne-agreement

Take down policy

If you believe that this document breaches copyright please contact us at:

pure-support@ou.nl

providing details and we will investigate your claim.

Downloaded from https://research.ou.nl/ on date: 26 Apr. 2023 


\title{
How IT-enabled dynamic capabilities add value to the development of innovation capabilities: an empirical investigation
}

\author{
Rogier van de Wetering ${ }^{1} \&$ Maaike Besuyen ${ }^{2}$ \\ ${ }^{1}$ Faculty of Management, Science and Technology, Open University of the Netherlands, Valkenburgerweg 177, 6419 AT Heerlen, the Netherlands \\ rogier.vandewetering@ou.nl \\ ${ }^{1}$ Albert Heijn, IT stores, Haarlem, the Netherlands \\ m.besuyen@gmail.com
}

\begin{abstract}
The development of innovation capabilities is crucial for modern organizations. This research builds on the dynamic capability view and aims to understand how a specific quality of the IT infrastructure, i.e., IT flexibility, through the development of IT-enabled dynamic capabilities (ITDCs), leads to innovation gains. We empirically validate our main research questions and associated research model using multiple regression analyses on a sample of 138 Dutch firms. We gathered this data through respondent-driven sampling. This study uncovers that IT flexibility is a key attribute in the development of ITDCs. Also, our empirical results support that claim that the development of ITDCs fosters organizations' capability to innovate. These outcomes substantiate our claim that IT is an essential facilitator for innovation capabilities. We also uncovered that the effect of IT flexibility, through ITDCs on innovation capabilities is independent of the complexity of the market. As such, this work contributes to the current practical and theoretical IT and business knowledge base.
\end{abstract}

Keywords: Resource-based View of the firm (RBV), dynamic capability View (DCV), IT flexibility, IT-enabled dynamic capabilities, innovation capabilities, environmental complexity.

\section{INTRODUCTION}

Many organizations face intense pressure to transform their current business model and operations toward more sustainability, and innovation-driven organization (Dao, Langella, \& Carbo, 2011; Hanelt, Busse, \& Kolbe, 2016; Seidel, Recker, \& Vom Brocke, 2013). Major technology trends and developments like big data analytics, robotics, Internet of Things, and the rise of artificial intelligence are making firms' ability to change and adapt its organizations' structure, architecture, and people as crucial as its competitive strategy. However, merely possessing valuable, rare, inimitable and non-substitutional (VRIN) information technology (IT) resources within this day and age, is not enough to enhance organizational benefits and to maintain a competitive edge (Eisenhardt \& Martin, 2000). Organizational capabilities, rather than IT assets, resources or products, have been suggested to be a critical competitive differentiator (Strønen, Hoholm, Kværner, \& Støme, 2017; Teece, Pisano, \& Shuen, 1997). These capabilities represent an organization's potential to achieve specific business strategies and management objectives using focused deployment and are considered the building blocks on which organizations compete within the business ecosystem. Eisenhardt \& Martin (2000) suggested that managers use these particular capabilities through integrating, building and reconfiguring internal and external competencies to achieve competitive advantage, rather than 'simply' possessing the capabilities (Eisenhardt \& Martin, 2000; Strønen et al., 2017).

As the need to innovate increases in today's business environment, IT is often an important supporting factor through adapting to its environment and meeting new demands while maintaining quality and efficiency (Rowe, Besson, \& Hemon, 2017; Van de Wetering, Mikalef, \& Helms, 2017). Previous studies posited the term IT capabilities, in this particular context, in an attempt to measure a firm's proficiency in exploiting its IT assets. IT capabilities - firms' ability to mobilize and deploy IT-based resources in combination or copresent with other resources and capabilities in order to differentiate from competition (Bharadwaj, 2000)—, have been viewed by past literature as complex, multidimensional constructs (Kim, Shin, Kim, \& Lee, 2011; Pavlou \& El Sawy, 2006; Sambamurthy, Bharadwaj, \& Grover, 2003). Although there is a growing body of knowledge underscoring the pivotal role IT-enabled capabilities in the process of enhancing an organization's competitive or financial performance gains (Kim et al., 2011; Mikalef, Pateli, \& van de Wetering, 2016), there is considerably less scholarship about leveraging IT capabilities and obtaining innovation, and maintain a competitive edge in the business ecosystem through the development of IT-enabled dynamic capabilities (ITDCs) (Agarwal \& Selen, 2009; Mikalef et al., 2016; Wade \& Hulland, 2004). We define ITDCs as an organization's ability to leverage its IT assets, resources, and IT competencies, in combination with other organizational resources and capabilities, in order to address rapidly changing business environments (Mikalef et al., 2016). Organizations that optimally deploy and enable their assets, resources, and organizational IT capabilities are more innovative and effective, and more promptly respond to constitutional changes in industry and market conditions than competitors (Aral \& Weill, 2007). Hence, there is a clear call for scholars to investigate and unfold the mechanisms on how IT-enabled innovation is achieved, what the antecedent and conditioning role is of IT flexibility and ITDCs capabilities, and under which market conditions innovation can be achieved (El Sawy \& Pavlou, 2008; Mikalef \& Pateli, 2017; Van de Wetering, Mikalef, \& Helms, 2017). 
This chapter aims to investigate whether or not IT flexibility facilitates the formation of ITDCs, as well as if the development of ITDCs results in any significant innovation gains. Also, we want to explore how environmental complexity shapes the effects of ITDCs in this nomological path. We argue that ITDCs reflect a firm's capacity to utilize its flexible IT infrastructure to support evolutionary fitness with the external environment (Helfat \& Peteraf, 2009). In sum, we develop a conceptual model and empirically validate this model at 138 Dutch firms. Hence, in this article, we address three research questions:

"(1) To what extent does IT flexibility influence the formation of ITDCs, (II) what is the influence of ITDCs on a firm's innovation capability, and finally (III) what is the conditioning effect of environmental complexity on the above relationships?"

We structured this chapter as follows. In the next section, we outline the theoretical background and propose our research model. Next, we present that methods section, including the data collection and analyses procedures. Then, we present the outcomes of this research and discuss the results. This chapter ends with the limitations of our work, avenues for future research, and conclusions.

\section{BACKGROUND}

\section{Resource-based and dynamic capabilities view of the firm}

We ground this current work on the resource-based view of the firm (RBV), as well as the widely acknowledged dynamic capabilities view (DCV). The RBV provides a solid foundation upon which firms can identify and evaluate all relevant resources (including IT assets, infrastructure, resources, and capabilities) toward their importance and deploy them to achieve and sustain competitive advantage (Barney, 2001; Van de Wetering, Versendaal, \& Walraven, 2018).

Notwithstanding the theories' pivotal role in the literature, it does not explicitly address and define how they collectively should be leveraged to derive business value. The DCV addressed these particular shortcomings as a means for firms to evolve in changing environments and maintain a competitive edge (Schilke, 2014). The DCV has been one of the most influential theories and perspectives in the study of strategic management and information systems (IS) and attempts to explain — by extending the RBV-the processes through which a firm evolves in changing environments and maintains a competitive edge (Teece et al., 1997). Due to conditions of high environmental uncertainty, market volatility, and frequent change, scholars have raised questions regarding the rate to which traditional operational and existing 'resource-based' capabilities erode and cease to provide competitive gains (Drnevich \& Kriauciunas, 2011). In the context of IS literature, previous investigations examined how IS/IT and architectural assets and resources infused in organizational capabilities can help firms renew or reconfigure their existing mode of operating (Mikalef \& Pateli, 2017; Pavlou \& El Sawy, 2006; Van de Wetering, 2019) and which IT investments are deemed necessary to derive sustained competitive value (Kohli \& Grover, 2008).

Following the tenets of the DCV, previous scholarship argued that it is more relevant to identify the organizational and dynamic capabilities that should be targeted by IT, rather than the aggregation of IT capabilities (IT resources and IT competencies). If an organization can combine its IT resources and competencies with other organizational resources and capabilities to respond to changes in the business environment, they possess the so-called ITDCs (Mikalef et al., 2016).

\section{IT flexibility}

The configuration of all IT interlinked assets, systems, and components, network and communication facilities, and applications within the organization is called the IT infrastructure (Kim et al., 2011). IT flexibility refers to a shareable and reusable architecture, enabling IT resources to develop and support system components quickly, allowing the organization to be innovative and react to new market opportunities as business conditions change (Kim et al., 2011; Tallon \& Pinsonneault, 2011) and has emerged as a de facto standard (Wilkinson, 2006) for the development of the organization's IT infrastructure. The extant literature unfolded the value of IT flexibility as an enabler of digital business strategies (Overby, Bharadwaj, \& Sambamurthy, 2006; Sambamurthy et al., 2003) and as a critical component to adapt IT to changing circumstances (Bharadwaj, 2000; Ray, Muhanna, \& Barney, 2005).

Synthesis from past studies shows some key qualities can be defined concerning IT infrastructure flexibility. These are modularity (i.e., loose coupling), standardization, and transparency and scalability (Byrd \& Turner, 2000; Duncan, 1995; Tafti, Mithas, \& Krishnan, 2013). In particular, the collective and complementary effect of these qualities enables organizations to develop ITDCs that are essential to cope with changing conditions (Mikalef et al., 2016), facilitate IT-based competitive actions (Overby et al., 2006) and acts as a facilitator of evolutionary fitness and adaptiveness.

Based on the preceding discussion, we argue that higher levels of IT flexibility will enhance the formation of ITDCs. Hence, we define the following hypothesis:

\section{Hypothesis 1: IT flexibility positively affects the development of ITDCs.}

\section{Innovation capabilities}

Organizations continuously need to renew. This renewing process involves their processes, products, and services, and sometimes even their culture and identity. Innovation is a necessary condition to meet the demands of high volatile markets (Mikalef \& Pateli, 
2017; Strønen et al., 2017). Innovation capabilities can be defined as organizations' ability to generate innovations. These innovations include fundamental changes to products, services, or technologies where incremental innovations are just refinements of the same. We broadly distinguish two types of capabilities within the innovation spectrum, i.e., incremental and radical. An innovative incremental capability is defined as: 'an organization's ability to generate innovations that refine and reinforce existing products and services' (Subramaniam \& Youndt, 2005). Accordingly, a radical, innovative capability is the capability of an organization to generate innovations that substantially transform existing products, services, and technologies (Subramaniam \& Youndt, 2005).

Breznik and Hisrich (2014) stressed the importance to understand the relationship between dynamic capabilities and innovation capabilities. The dynamic capabilities view goes beyond heterogeneous firm resources and capabilities (Barney \& Clark, 2007, p. p. 257) and stresses the importance of grounding a business strategy in strong dynamic capabilities (Teece, 2014). Only dynamic capabilities support evolutionary fitness and innovation within the turbulent business ecosystem (Teece, 2009, p. 7) which helps organizations to create value and prosper in the marketplace (Kindström, Kowalkowski, \& Sandberg, 2013).

Finally, by leveraging ITDCs, organizations can gain access to previously unavailable sets of decision options which can ultimately enhance their ability to innovate and thus provide the potential for higher performance contributions (Drnevich \& Kriauciunas, 2011; Eisenhardt \& Martin, 2000). Hence, we expect that ITDCs will help organizations in the quest to incrementally and radically develop new processes, products, and services. Hence, we define the following:

\section{Hypothesis 2: ITDCs have a positive impact on the development of innovation capabilities}

Some studies argue that IT flexibility facilitates the development of innovation capabilities (Ahuja \& Chan, 2014). Recent scholarship also contends that the coevolution and the complex interactions of flexible IT infrastructures and organizational capabilities are considered cornerstones of innovation (Van de Wetering, Mikalef, \& Helms, 2017). Others studies claim that the impact of IT flexibility on innovation capability is indirect and that this effect is readily mediated by strategic IT alignment (Tallon \& Pinsonneault, 2011; Van de Wetering, Mikalef, \& Pateli, 2017). Hence, Tallon (2011) explains how IT flexibility creates digital options, which can help organizations transform and align IT with business strategy (Tallon \& Pinsonneault, 2011). Apart from this, researchers have argued that IT flexibility can strengthen the sensing, responding, and reconfiguration routines that are part of ITDCs. Overall, the combined effect of ITDCs and flexibility offered by the organization's IT infrastructure is expected to enhance innovation capabilities. Hence, we define the following hypothesis:

\section{Hypothesis 3: ITDCs positively mediate the effect of IT flexibility on innovation capabilities}

\section{Environmental complexity}

In today's business environment, unpredictable rapid changes and uncertainties have become 'the new normal' (Kim et al., 2011). Research has acknowledged the influential role of external environmental factors on the relationship between IT capabilities and business outcomes (Chen et al., 2014). These environmental factors are environmental hostility, dynamism, and complexity (Chen et al., 2014). Hostility defines the scarcity of resources and level of competition; dynamism denotes the unpredictability of environmental changes, and complexity concerns the diversity of the market and the heterogeneity and range of an industry and/or an organization's activities (Chen et al., 2014; Mikalef \& Pateli, 2017; Wade \& Hulland, 2004). Unexpected market changes can force organizations to change their business strategy, thus, sensing the need for developing new combinations of IT capabilities and resources becomes a necessity in dynamic markets (Strønen et al., 2017; Tallon \& Pinsonneault, 2011; Teece et al., 1997).

Studies have acknowledged the permeation of IT in all aspects of organizations and the importance of IT assets, resources, competence, and capabilities in enabling business abilities that help firms survive, thrive (Aral \& Weill, 2007; Dao et al., 2011; Kim et al., 2011), and support evolutionary fitness with the external environment (Helfat \& Peteraf, 2009). Innovation capabilities are crucial for organizations to achieve congruence with this dynamic environment (Kindström et al., 2013; Teece, 2007, 2010; Van de Wetering, Mikalef, \& Helms, 2017). Previous research contends that a firm's proficiency in IT capability development and flexible IT infrastructures in highly complex environments is strongly associated with efficient operations management and competitive process capabilities (Byrd \& Turner, 2000; Rai \& Tang, 2010; Wade \& Hulland, 2004). That is, organizations that have a sophisticated IT capability and flexible infrastructures are better equipped to sense, analyze, seize opportunities, and more likely to transform and disseminate information and business opportunities in the day-to-day operations. Thus, sensing, responding, and innovation capabilities become a necessity in uncertain environments. We, therefore, assume that the environmental complexity will be an essential catalyst for the likely effect that ITDCs have on innovation capabilities.

Based on the above rationale, we formulate the following two hypotheses:

Hypothesis 4a: A considerable degree of environmental complexity positively moderates the effect of IT flexibility on the development of ITDCs.

Hypothesis 4b: A considerable degree of environmental complexity positively moderates the effect of ITDCs on the development of innovation capabilities. 


\section{EMPIRICAL STUDY}

\section{Research approach and data collection}

This research follows a positivistic research philosophy. This philosophy emphasizes that new knowledge can only be acquired through the correct application of a strictly scientific method where the focus is on discovering observable and measurable facts (Saunders, Lewis, \& Thornhill, 2016). The method should be designed to yield pure data and facts which are not influenced by bias or interpretations (Saunders et al., 2016). We apply quantitative research because of the highly-structured data collection techniques. Through a deductive approach, we use and analyze data to evaluate a priori defined hypotheses related to an existing theory. The developed hypotheses will be tested and confirmed or refuted, allowing further development of the theory (Saunders et al., 2016).

We approached respondents directly through our (social) networks. This method is called respondent-driven sampling. We only identified and selected respondents that have sufficient knowledge and experience to avoid uninformed and unreliable responses. Thus, the target audience was selected based on convenience sampling. We identified Chief Information Officers (CIO's), Chief Executive Officers (CEO's), Chief Technology Officers (CTO's), innovation managers, IT managers and enterprise architects to be most familiar with our study concepts. During the data collection, we kept track of which respondent from which organization completed the survey, to make sure that every organization completed the survey only once. We also ensured that different organizations from a wide range of businesses, industries of various sizes were included. Respondents were given an incentive to take part in the survey. They were offered a benchmark report to gain insights on how well their organization scores compared to others in the same industry.

The data collection phase started on the $26^{\text {th }}$ of February 2018 and ended on April $9^{\text {th }}$ of 2018. In total, 610 respondents from different organizations were asked to fill in the survey. Based on the final response, a total of 138 usable questionnaires could be included for the analyses, i.e., a response rate of $23 \%$ which is acceptable for these type of studies (Baruch \& Holtom, 2008). The majority of responses were from the private sector $62,3 \%, 30,4 \%$ from the public sector and a small percentage from non-profit $(4,3 \%)$, nongovernmental organizations $(1,4 \%)$ and other categories $(1,4 \%)$. Most responses were from large organizations with $250+$ employees (71\%), 50-249 employees (14\%), 10-49 employees (9\%), and the remaining 6\% had less than 9 employees. More than half of the organizations were founded over 50 years ago.

We controlled for potential common method bias (CMB). We, thus, performed Harman's single factor test using IBM SPSS Statistics ${ }^{\mathrm{TM}}$ v25 on our main study constructs. Hence, we loaded all construct variables on to a single construct in an Exploratory Factor Analysis (EFA). Outcomes of this analysis showed that no single factor attributes to the majority of the variance. We, therefore, conclude that our sample is not affected by CMB (Podsakoff, MacKenzie, Lee, \& Podsakoff, 2003).

\section{Items and constructs}

The survey started with questions on the background information of the organization, such as size, industry, and age of the organization. All the primary constructs of our based on past empirical and validated work to increase the internal validity of the questions (Chen et al., 2014; Mikalef et al., 2016; Newkirk \& Lederer, 2006). The entire survey was pre-tested by six Master students and a small panel of expert, including three managers/consultants from practice and two academics to ensure face and content validity. We evaluated all survey items on a 7-point Likert scale. We included the entire survey in Appendix A.

We included the following dimensions for IT flexibility, i.e.: (1) loose coupling, (2) standardization, (3) transparency, and (4) scalability. The following routines for ITDCs were adopted: (1) sensing, (2I) learning, (3) coordinating, (4) integrating and (5) reconfiguring routines (Mikalef et al., 2016; Pavlou \& El Sawy, 2011; Teece, 2007; Teece et al., 1997). Next, the measures for the two types of innovation capabilities (i.e., incremental and radical) are based on the items provided by Subramaniam and Youndt (2005). Finally, we used the construct items assessed by (Chen et al., 2014; Mikalef \& Pateli, 2017; Newkirk \& Lederer, 2006) to measure the degree of environmental heterogeneity, complexity.

\section{DATA PREPARATION AND ANALYSES}

We analyzed the obtained data using the software package IBM SPSS Statistics ${ }^{\mathrm{TM}}$ V25 and hence test the hypotheses. All constructs and measurement items were subjected to various assessments, including internal consistency, reliability, construct, and discriminant validity assessments. For operationalization purposes, we conceived all the model's constructs to be reflective of nature. Hence, the manifest variables are affected by the latent variables (Wetzels, Odekerken-Schröder, \& Van Oppen, 2009). Hence, at the construct level, we checked internal consistency reliability using Cronbach's Alpha values and check whether they all exceeded the threshold of 0.7 (Santos, 1999). Also, we calculated the composite reliability (CR) values for each construct as this measure takes into account the loadings of the manifest variables (Hair Jr, Hult, Ringle, \& Sarstedt, 2016). Typically, CR values should be between 0.60 and 0.90 , as is the case in our research (see Table 1). Also, we assessed the construct-to-item loadings. We assessed the convergent validity by examining if the average variance extracted (AVE) of each construct is above the lower limit of 0.50 (Fornell \& Larcker, 1981). Next, to convergent validity, we also discriminant validity through three different, but related tests (Farrell, 2010). First, we examined if the cross-loadings on other latent constructs are less than the outer loading on the associated construct. Next, we assessed the FornellLarcker criterion. In doing so, we investigated if the square root of the AVEs of all constructs is larger than the cross-correlation. All correlations among all constructs were below the common threshold (0.70). The outcomes of these assessments in Table 1 suggest that 
the constructs are valid and reliable.

We used principal component analyses (PCA), and the preceding Kaiser-Meyer-Olkin measure of sampling adequacy (KMO) (Kaiser, 1974) scores and Bartlett's test of sphericity tests, to assess whether or not we could reduce the multiple items per construct to a single construct measure. Hence, we subsequently used the average values of the constructs items to represent the latent constructs.

Before running the multiple regression analyses, there are some necessary assumptions to be checked that make sure this dataset is appropriate to use linear regression to give a valid output. First, we excluded seven detected outliers to prevent any adverse effect on the regression analyses. Next, we checked the data for normality using a normal P-P plot. We used scatterplots for homoscedasticity analyses. We met all the underlying assumptions. Therefore, the linear regression analyses results can be considered valid. We used a macro for SPSS called 'PROCESS' (Hayes, 2013) to run our analyses.

\begin{tabular}{lllllllllllll}
\hline & $\mathbf{1 .}$ & $\mathbf{2 .}$ & $\mathbf{3 .}$ & $\mathbf{4 .}$ & $\mathbf{5 .}$ & $\mathbf{6 .}$ & $\mathbf{7 .}$ & $\mathbf{8 .}$ & $\mathbf{9 .}$ & $\mathbf{1 0 .}$ & $\mathbf{1 1 .}$ & $\mathbf{1 2 .}$ \\
\hline 1. Loose Coupling & $\mathbf{0 . 8 0}$ & & & & & & & & & & & \\
2. Standardization & 0.29 & $\mathbf{0 . 7 6}$ & & & & & & & & & \\
3. Transparency & 0.60 & 0.48 & $\mathbf{0 . 7 9}$ & & & & & & & & \\
4. Scalability & 0.56 & 0.35 & 0.51 & $\mathbf{0 . 8 8}$ & & & & & & & \\
5. Sensing & 0.38 & 0.34 & 0.39 & 0.35 & $\mathbf{0 . 8 4}$ & & & & & & \\
6. Learning & 0.40 & 0.35 & 0.42 & 0.34 & 0.58 & $\mathbf{0 . 9 1}$ & & & & & \\
7. Coordinating & 0.47 & 0.45 & 0.46 & 0.46 & 0.61 & 0.59 & $\mathbf{0 . 8 7}$ & & & & \\
8. Integrating & 0.43 & 0.44 & 0.45 & 0.47 & 0.70 & 0.62 & 0.73 & $\mathbf{0 . 8 6}$ & & & \\
9. Reconfiguring & 0.58 & 0.28 & 0.48 & 0.47 & 0.64 & 0.57 & 0.66 & 0.65 & $\mathbf{0 . 8 4}$ & & & \\
10. Incremental innovation & 0.41 & 0.16 & 0.35 & 0.27 & 0.51 & 0.37 & 0.39 & 0.38 & 0.50 & $\mathbf{0 . 9 3}$ & & \\
11. Radical innovation & 0.40 & 0.20 & 0.43 & 0.25 & 0.48 & 0.37 & 0.43 & 0.38 & 0.47 & 0.66 & $\mathbf{0 . 9 2}$ & \\
12. Env. Complexity & 0.10 & 0.15 & 0.08 & 0.11 & 0.20 & 0.03 & 0.05 & 0.22 & 0.13 & 0.16 & 0.08 & $\mathbf{0 . 8 3}$ \\
& & & & & & & & & & & & \\
Cronbach`s Alpha & .89 & .90 & .85 & .84 & .86 & .93 & .89 & .89 & .86 & .93 & .92 & .78 \\
Composite reliability & .92 & .88 & .89 & .93 & .91 & .95 & .93 & .93 & .91 & .96 & .95 & .87 \\
AVE & .65 & .59 & .59 & .76 & .71 & .71 & .76 & .76 & .71 & .88 & .86 & .70 \\
\hline
\end{tabular}

Table 1. Assessment of convergent and discriminant validity of the model's constructs.

\section{RESULTS}

We use PROCESS to assess our research model, thereby examining the proposed complete set of hypotheses. Results of the regression model are as follows. $33 \%$ of the variance for innovation capabilities can be explained $\left(R^{2}=.33\right)$ through the research model. The model is significant $(p=<.05)$.

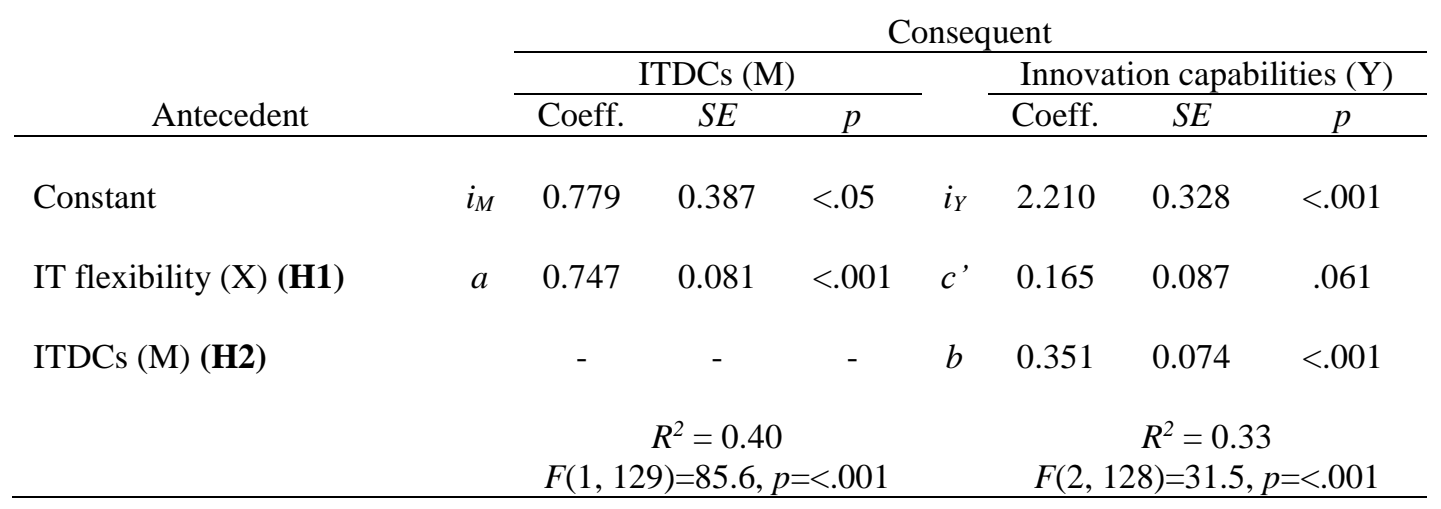

Table 2: Model coefficients for the mediating model

The results in Table 2 support $\mathbf{H 1}$ in that two organizations that differ by one degree in the flexibility of their IT infrastructure differ by 0.747 units in their indication of being effective in using IT systems to sense, integrate, coordinate, reconfigure and learn. The regression coefficient for ITDCs on innovation capabilities, $b=0.351$, subsequently supports $\mathbf{H 2}$, i.e., two organizations having the same degree of IT flexibility but differ by one unit in their ITDCs are estimated to be relatively stronger in their perceived innovation capabilities by 0.351 units. 


\section{Mediation model}

We used ordinary least squares path analysis to analyze the mediation effects. Hence, IT flexibility indirectly influences innovation capabilities through its effect on ITDCs. This indirect effect was calculated through the product of path $a$ and path $b(a b)$. The bootstrap confidence interval for this indirect using 5,000 bootstrap samples, is between 0.160 and 0.378 . This confidence interval is entirely above zero. Therefore, this outcome supports the conclusion that the indirect effect is positive and, thus, provides evidence for ITDCs role as a facilitator of the effect of IT flexibility on innovation capabilities. Next, we will analyze if this effect is fully mediated or partially. The estimated direct effect (c') of IT flexibility on innovation capabilities is $c^{\prime}=0.165$, but misses statistical significance using an $\alpha=0.05$ decision criterion, $t(2,128)=1.894, p=0.061$. So, this research finds no evidence of IT flexibility affecting innovation capabilities independent of the mediated effect of ITDCs. The total effect of IT flexibility on innovation capabilities is $\mathrm{c}=$ 0.427 , and since c' is not statistically significant, ITDCs is marked as a complete mediator of the interaction, supporting H3. What this means is, that without the influence of ITDCs the flexibility of an organizations' architecture cannot affect its capability to innovate.

\section{Moderated mediation model}

Although the estimated difference in strength of ITDCs caused by IT flexibility is significant for $b=0.747$ at $p=<0.001$, the regression coefficients for the direct effect of environmental complexity on ITDCs $a_{2}=-0.043, p=0.868$, as well as the interaction effect IT flexibility and environmental complexity $a_{3}=.019, p=0.728$ miss statistical significance. So, this research rejects H4a as it finds no evidence for the conditioning effects of environmental complexity. The absence of a direct moderation effect means no two conditional direct effects can be considered statistically different from each other. The same applies to the effect of environmental complexity on the development of innovation capabilities through ITDCs. The direct effect of environmental complexity on innovation capabilities is not significant at $b_{2}=-0.124, p=0.475$. Next, the product of ITDCs and environmental complexity also misses statistical significance at $\mathrm{b} 3=.036, \mathrm{p}=0.367$. Thus, the degree of environmental complexity does not moderate the effect of ITDCs on the development of innovation capabilities. Therefore, we also reject $\mathbf{H 4 b}$; a particularity that we will discuss.

Figure 1 summarizes all the assessed relationships.

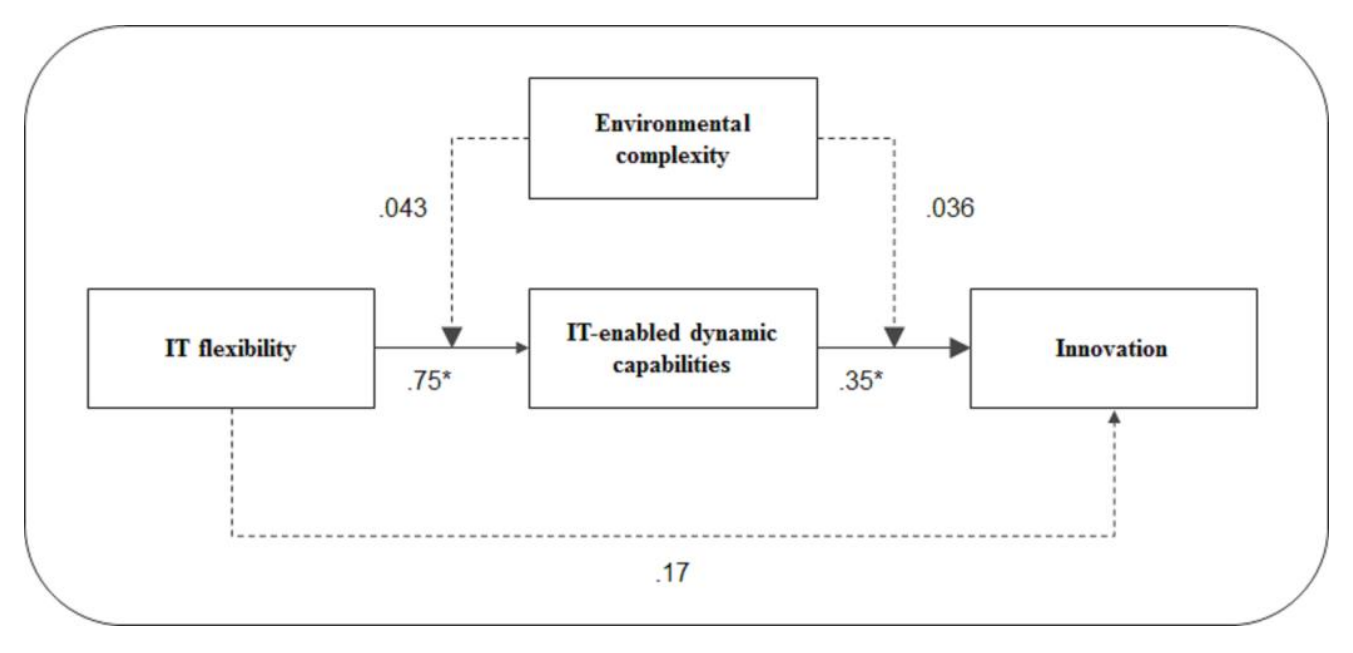

Figure 1: Estimated causal relationships of the research model. The * is used to denote a significant relationship.

\section{DISCUSSION}

This study examined if IT flexibility facilitates the formation of ITDCs, as well as if the development of ITDCs results in any significant innovation gains. An important outcome of this study is that the development of ITDCs is positively affected by the degree of IT flexibility. This outcome confirms previous findings by Mikalef et al. (Mikalef et al., 2016), although we even find an even stronger beta coefficient $(\beta=0.75)$.

Previously, Breznik and Hisrich (2014) called for empirical validation of the relationship between ITDCs and an organization's innovation capabilities. Our study finds a significant relationship between ITDCs and organization's aggregated innovation capabilities $(\beta=0.351)$. The combined impact of IT flexibility and ITDCs explain 33\% of the variance in innovation capabilities. These outcomes also corroborate with previous claims that strengthening ITDCs in isolation is not sufficient to substantially enhance organizations' capability to innovate (R. Van de Wetering, P. Mikalef, \& A. Pateli, 2017). Therefore, our current study extends the current practical and theoretical knowledge base that has paid little attention to organizational innovativeness, and IT-enabled business transformations in complex environments.

We would expect that the previously discussed mediation effect would be moderated by environmental complexity (Strønen et al., 2017; Tallon \& Pinsonneault, 2011; Teece et al., 1997). However, we currently did not find any evidence to support that the diversity of the market fosters the value-adding effects of ITDCs. This outcome means that within our study, the effect of IT flexibility, through 
ITDCs on organizations' capability to innovate is not influenced by the market diversity. This rather weak conditioning effect might be attributed to a large part of the respondents that work in the public sector. Various respondents argued that environmental complexity questions were less relevant for their particular organizations (operating in the public sector and non-profit sector). Many other environmental factors can be taken into considerations.

This work has some interesting practical implications. Our study provides insights for organizations, mainly for IT and business managers, regarding the usage of IT to develop innovation capabilities. Hence, we highlight the importance of maintaining the organization's IT infrastructure modular, scalable, and transparent, but organizations should mainly strategically invest in developing their ITDCs. Thus, if organizations want to achieve significant innovation capability gains, it is strategically imperative to develop their respective capabilities to sense, learn, coordinate, integrate, and reconfigure.

\section{FUTURE RESEARCH DIRECTIONS}

Despite its contributions, this study includes several limitations. First, we conveniently sampled our data. A potential disadvantage of this particular method is that our sample might not be representative of the full population (Heckathorn, 2002). A stratified sampling method that a priori includes various subgroups within a population remedies this. Second, we only asked a single respondent to fill in the survey. Future research could employ a matched-pair approach through which independent and dependent constructs are provided to different stakeholders within the organization. An alternative could also be to have multiple respondents per organization fill in the survey to gain a holistic view of the capabilities and environment of the organization. Third, our obtained survey data included various demographic variables (e.g., organization type, size). However, our empirical analyses did not take into account the possible differences among sub-groups of organizations. Also, comparing the strength of the relationships across the organization from different countries might well contribute to the generalizability of our findings. Finally, a more substantial sample space could then also contribute to more robust results.

\section{CONCLUSION}

To conclude, ITDCs are essential for the organization in the modern age. Our study tried to explain how organizations - that operate in turbulent environments — can differentiate to stay competitive, considering that they must evolve and reconfigure their processes to drive innovation. By considering the key antecedents and mechanisms through which innovation capabilities can foundationally be enhanced, we make valuable contributions to the literature. Our work also serves as a basis for future investigations.

\section{ACKNOWLEDGMENTS}

We want to thank all the organization that participated in this study. Also, we are thankful to the Master Business Process Management and IT student Bart-Jan Otten, Selena Dinsbach, Yakup Bagcan, Elgine Gumbs, and Sebastiaan van der Gugten for their efforts in collecting the data.

\section{REFERENCES}

Agarwal, R., \& Selen, W. (2009). Dynamic capability building in service value networks for achieving service innovation. Decision Sciences, 40(3), 431-475.

Ahuja, S., \& Chan, Y. (2014). The enabling role of IT in frugal innovation. Paper presented at the International Conference on Information Systems (ICIS).

Aral, S., \& Weill, P. (2007). IT assets, organizational capabilities, and firm performance: How resource allocations and organizational differences explain performance variation. Organization Science, 18(5), 763-780.

Barney, J. B. (2001). Resource-based theories of competitive advantage: A ten-year retrospective on the resource-based view. Journal of management, 27(6), 643-650.

Barney, J. B., \& Clark, D. N. (2007). Resource-based theory: Creating and sustaining competitive advantage: Oxford University Press on Demand.

Baruch, Y., \& Holtom, B. C. (2008). Survey response rate levels and trends in organizational research. Human relations, 61(8), 1139-1160.

Bharadwaj, A. S. (2000). A resource-based perspective on information technology capability and firm performance: an empirical investigation. MIS Quarterly, 169-196.

Breznik, L., \& Hisrich, R. (2014). Dynamic capabilities vs. innovation capability: are they related? Journal of Small Business and Enterprise Development, 21(3), 368-384. doi:10.1108/JSBED-02-2014-0018

Byrd, T. A., \& Turner, D. E. (2000). Measuring the flexibility of information technology infrastructure: Exploratory analysis of a construct. Journal of Management Information Systems, 17(1), 167-208. 
Chen, Y., Wang, Y., Nevo, S., Jin, J., Wang, L., \& Chow, W. S. (2014). IT capability and organizational performance: the roles of business process agility and environmental factors. European Journal of Information Systems, 23(3), 326-342.

Dao, V., Langella, I., \& Carbo, J. (2011). From green to sustainability: Information Technology and an integrated sustainability framework. The Journal of Strategic Information Systems, 20(1), 63-79.

Drnevich, P. L., \& Kriauciunas, A. P. (2011). Clarifying the conditions and limits of the contributions of ordinary and dynamic capabilities to relative firm performance. Strategic Management Journal, 32(3), 254-279.

Duncan, N. B. (1995). Capturing flexibility of information technology infrastructure: A study of resource characteristics and their measure. Journal of Management Information Systems, 37-57.

Eisenhardt, K. M., \& Martin, J. A. (2000). Dynamic capabilities: what are they? Strategic Management Journal, 2l(10-11), 1105-1121.

El Sawy, O. A., \& Pavlou, P. A. (2008). IT-enabled business capabilities for turbulent environments. MIS Quarterly Executive (2008), 7(3), 139-150.

Farrell, A. M. (2010). Insufficient discriminant validity: A comment on Bove, Pervan, Beatty, and Shiu (2009). Journal of Business Research, 63(3), 324-327.

Fornell, C., \& Larcker, D. (1981). Evaluating structural equation models with unobservable variables and measurement error. Journal of Marketing Research, 18(1), 39-50.

Hair Jr, J. F., Hult, G. T. M., Ringle, C., \& Sarstedt, M. (2016). A primer on partial least squares structural equation modeling (PLS-SEM): Sage Publications.

Hanelt, A., Busse, S., \& Kolbe, L. M. (2016). Driving business transformation toward sustainability: exploring the impact of supporting IS on the performance contribution of eco-innovations. Information Systems Journal.

Hayes, A. F. (2013). Introduction to mediation, moderation, and conditional process analysis: A regressionbased approach: Guilford Press.

Heckathorn, D. D. (2002). Respondent-driven sampling II: deriving valid population estimates from chainreferral samples of hidden populations. Social problems, 49(1), 11-34.

Helfat, C. E., \& Peteraf, M. A. (2009). Understanding dynamic capabilities: progress along a developmental path. Strategic organization, 7(1), 91-102.

Kaiser, H. F. (1974). An index of factorial simplicity. Psychometrika, 39(1), 31-36.

Kim, G., Shin, B., Kim, K. K., \& Lee, H. G. (2011). IT capabilities, process-oriented dynamic capabilities, and firm financial performance. Journal of the Association for Information Systems, 12(7), 487.

Kindström, D., Kowalkowski, C., \& Sandberg, E. (2013). Enabling service innovation: A dynamic capabilities approach. Journal of Business Research, 66(8), 1063-1073.

Kohli, R., \& Grover, V. (2008). Business value of IT: An essay on expanding research directions to keep up with the times. Journal of the Association for Information Systems, 9(1), 23.

Mikalef, P., \& Pateli, A. (2017). Information technology-enabled dynamic capabilities and their indirect effect on competitive performance: Findings from PLS-SEM and fsQCA. Journal of Business Research, 70, 116. doi:10.1016/j.jbusres.2016.09.004

Mikalef, P., Pateli, A., \& van de Wetering, R. (2016). IT flexibility and competitive performance: The mediating role of IT-enabled dynamic capabilities. Paper presented at the 24th European Conference on Information Systems (ECIS).

Newkirk, H. E., \& Lederer, A. L. (2006). The effectiveness of strategic information systems planning under environmental uncertainty. Information \& Management, 43(4), 481-501. doi:https://doi.org/10.1016/j.im.2005.12.001

Overby, E., Bharadwaj, A., \& Sambamurthy, V. (2006). Enterprise agility and the enabling role of information technology. European Journal of Information Systems, 15(2), 120-131.

Pavlou, P. A., \& El Sawy, O. A. (2006). From IT leveraging competence to competitive advantage in turbulent environments: The case of new product development. Information Systems Research, 17(3), 198-227.

Pavlou, P. A., \& El Sawy, O. A. (2011). Understanding the elusive black box of dynamic capabilities. Decision Sciences, 42(1), 239-273. 
Podsakoff, P. M., MacKenzie, S. B., Lee, J.-Y., \& Podsakoff, N. P. (2003). Common method biases in behavioral research: A critical review of the literature and recommended remedies. Journal of Applied Psychology, 88(5), 879.

Rai, A., \& Tang, X. (2010). Leveraging IT capabilities and competitive process capabilities for the management of interorganizational relationship portfolios. Information Systems Research, 21(3), 516-542.

Ray, G., Muhanna, W. A., \& Barney, J. B. (2005). Information technology and the performance of the customer service process: A resource-based analysis. MIS Quarterly, 625-652.

Rowe, F., Besson, P., \& Hemon, A. (2017). SOCIO-TECHNICAL INERTIA, DYNAMIC CAPABILITIES AND ENVIRONMENTAL UNCERTAINTY: SENIOR MANAGEMENT VIEWS AND IMPLICATIONS FOR ORGANIZATIONAL TRANSFORMATION. Paper presented at the European Conference on Information Systems (ECIS), Portugal.

Sambamurthy, V., Bharadwaj, A., \& Grover, V. (2003). Shaping agility through digital options: Reconceptualizing the role of information technology in contemporary firms. MIS Quarterly, 237-263.

Santos, J. R. A. (1999). Cronbach's alpha: A tool for assessing the reliability of scales. Journal of extension, $37(2), 1-5$.

Saunders, M., Lewis, P., \& Thornhill, A. (2016). Research methods for business students (Seventh ed.): Pearson Education.

Schilke, O. (2014). On the contingent value of dynamic capabilities for competitive advantage: The nonlinear moderating effect of environmental dynamism. Strategic Management Journal, 35(2), 179-203.

Seidel, S., Recker, J. C., \& Vom Brocke, J. (2013). Sensemaking and sustainable practicing: functional affordances of information systems in green transformations. Management Information Systems Quarterly, 37(4), 1275-1299.

Strønen, F., Hoholm, T., Kværner, K., \& Støme, L. N. (2017). Dynamic capabilities and innovation capabilities: The case of the 'Innovation Clinic'. Journal of Entrepreneurship, 13(1), 89-116. doi:10.7341/20171314

Subramaniam, M., \& Youndt, M. A. (2005). The influence of intellectual capital on the types of innovative capabilities. Academy of Management Journal, 48(3), 450-463.

Tafti, A., Mithas, S., \& Krishnan, M. S. (2013). The effect of information technology-enabled flexibility on formation and market value of alliances. Management science, 59(1), 207-225.

Tallon, P. P., \& Pinsonneault, A. (2011). Competing perspectives on the link between strategic information technology alignment and organizational agility: insights from a mediation model. MIS quarterly, 463486.

Teece, D. J. (2007). Explicating dynamic capabilities: the nature and microfoundations of (sustainable) enterprise performance. Strategic Management Journal, 28(13), 1319-1350.

Teece, D. J. (2010). Business models, business strategy and innovation. Long range planning, 43(2), 172-194.

Teece, D. J. (2014). The foundations of enterprise performance: Dynamic and ordinary capabilities in an (economic) theory of firms. Academy of management perspectives, 28(4), 328-352.

Teece, D. J., Pisano, G., \& Shuen, A. (1997). Dynamic capabilities and strategic management. Strategic management journal, 509-533.

Van de Wetering, R. (2019). Dynamic Enterprise Architecture Capabilities: Conceptualization and Validation. In: Abramowicz W., Corchuelo R. (eds) Business Information Systems. BIS 2019. Lecture Notes in Business Information Processing, vol 354. Springer, Cham

Van de Wetering, R., Mikalef, P., \& Helms, R. (2017). Driving organizational sustainability-oriented innovation capabilities: a complex adaptive systems perspective. Current Opinion in Environmental Sustainability, 28, 71-79.

Van de Wetering, R., Mikalef, P., \& Pateli, A. (2017, September 4-5, 2017). How strategic alignment of IT flexibility, a firm's networking capability, and absorptive capacity influences firm innovation. Paper presented at the 11th Mediterranean Conference on Information Systems (MCIS). Genoa, Italy.

Van de Wetering, R., Mikalef, P., \& Pateli, A. (2017, June 5-10, 2017). A strategic alignment model for IT flexibility and dynamic capabilities: toward an assessment tool. Paper presented at the Twenty-Fifth European Conference on Information Systems (ECIS), Guimarães, Portugal.

Van de Wetering, R., Versendaal, J., \& Walraven, P. (2018, August 16-18, 2018). Examining the relationship between a hospital's IT infrastructure capability and digital capabilities: a resource-based perspective. 
Paper presented at the Twenty-fourth Americas Conference on Information Systems (AMCIS), New Orleans.

Wade, M., \& Hulland, J. (2004). Review: The resource-based view and information systems research: Review, extension, and suggestions for future research. MIS Quarterly, 28(1), 107-142.

Wetzels, M., Odekerken-Schröder, G., \& Van Oppen, C. (2009). Using PLS path modeling for assessing hierarchical construct models: guidelines and empirical illustration. MIS Quarterly, 33(1), 177-195.

Wilkinson, M. (2006). Designing an 'adaptive' enterprise architecture. BT Technology Journal, 24(4), 81-92.

\section{KEY TERMS AND DEFINITIONS}

- IT-enabled dynamic capabilities (ITDCs): Firm's ability to leverage its IT resources and IT competencies, in combination with other organizational resources and capabilities, to address rapidly changing business environments.

- Organizational capabilities: An organization's ability to achieve specific business strategies and management objectives using focused deployment and are considered the building blocks on which firms compete within the business ecosystem.

- Incremental innovation capability: organizations' potential to generate innovations that refine and reinforce existing products and services.

- Radical innovation capability: organizations' the capability of an organization to generate innovations that substantially transform existing products, services, and technologies.

- IT flexibility: the degree of decomposition of an organization's IT portfolio into loosely coupled subsystems that communicate through standardized interfaces.

- IT capability: firms' ability to mobilize and deploy IT-based resources in combination or co-present with other resources and capabilities in order to differentiate from the competition.

- Environmental complexity: the heterogeneity and range of industry and/or an organization's activities.

\section{APPENDIX: SURVEY ITEMS}

\begin{tabular}{|c|c|c|c|}
\hline \multirow{2}{*}{\multicolumn{2}{|c|}{$\begin{array}{l}\text { IT flexibility } \\
\text { To what extent do you agree with the following statements? (1-totally disagree, 7-totally agree) } \\
\text { Modularity }\end{array}$}} & \multirow[b]{3}{*}{ Mean } & \multirow[b]{3}{*}{ S.D. } \\
\hline & & & \\
\hline$\alpha=.89$ & \begin{tabular}{l|l}
$\mathrm{KMO}=.83$ \\
\end{tabular} & & \\
\hline [Mod 1] & Our information systems are highly modular. & 4.28 & 1.580 \\
\hline$[$ Mod 2] & $\begin{array}{l}\text { The manner in which the components of our information systems are organized } \\
\text { and integrated allows for rapid changes. }\end{array}$ & 3.97 & 1.691 \\
\hline [Mod 3] & $\begin{array}{l}\text { Functionality can be quickly added to critical applications based on end-user } \\
\text { requests }\end{array}$ & 4.22 & 1.720 \\
\hline$[\operatorname{Mod} 4]$ & Exchanging or modifying single components does not affect our IT infrastructure. & 4.42 & 1.699 \\
\hline [Mod 5] & $\begin{array}{l}\text { Organizational IT infrastructure and applications are developed on the basis of } \\
\text { minimal unnecessary interdependencies }\end{array}$ & 4.33 & 1.581 \\
\hline [Mod 6] & Organizational IT infrastructure and applications are loosely coupled. & 4.23 & 1.544 \\
\hline \multicolumn{2}{|c|}{ Transparency } & \multirow[b]{2}{*}{ Mean } & \multirow[b]{2}{*}{ S.D. } \\
\hline$\alpha=.85$ & $\mathrm{KMO}=.78$ & & \\
\hline [Trns 1] & Remote users can seamlessly access centralized data and processes & 5.16 & 1.671 \\
\hline [Trns 2] & Our user interfaces provide transparent access to all platforms and applications & 4.44 & 1.776 \\
\hline [Trns 3] & \multirow{2}{*}{ Software applications can be easily transported and used across multiple platforms } & 3.99 & 1.814 \\
\hline [Trns 4] & & 3.97 & 1.771 \\
\hline [Trns 5] & $\begin{array}{l}\text { Our firm offers multiple interfaces or entry points (e.g., web access) to external } \\
\text { users }\end{array}$ & 4.62 & 1.772 \\
\hline \multicolumn{2}{|c|}{ Standardization } & \multirow[b]{2}{*}{ Mean } & \multirow[b]{2}{*}{ S.D. } \\
\hline$\alpha=.90$ & $\mathrm{KMO}=.76$ & & \\
\hline [Stnd 1] & $\begin{array}{l}\text { We have established corporate rules and standards for hardware and operating } \\
\text { systems to ensure platform compatibility. }\end{array}$ & 5.02 & 1.623 \\
\hline [Stnd 2] & $\begin{array}{l}\text { We have identified and standardized data to be shared across systems and } \\
\text { business units. }\end{array}$ & 4.53 & 1.576 \\
\hline [Stnd 3] & $\begin{array}{l}\text { Our systems are developed based on specifications that enable electronic links to } \\
\text { external parties. }\end{array}$ & 4.51 & 1.613 \\
\hline [Stnd 4] & Organizational IT infrastructure are developed based on compliance guidelines. & 5.30 & 1.448 \\
\hline
\end{tabular}




\begin{tabular}{|c|c|c|c|}
\hline [Stnd 5] & Organizational IT applications are developed based on compliance guidelines. & 5.20 & \multirow[b]{3}{*}{ S.D. } \\
\hline \multicolumn{2}{|r|}{ 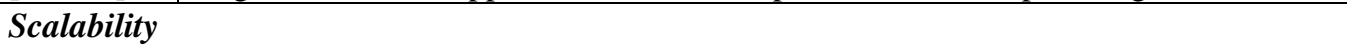 } & \multirow[b]{2}{*}{ Mean } & \\
\hline$\alpha=.83$ & $\mathrm{KMO}=.82$ & & \\
\hline [Scal 1] & Our IT infrastructure easily compensates peaks in transaction volumes. & 5.00 & 1.460 \\
\hline [Scal 2] & Our information systems are scalable. & 5.05 & 1.457 \\
\hline [Scal 3] & Our IT infrastructure offers sufficient capacity in order to fulfil additional orders. & 5.32 & 1.424 \\
\hline [Scal 4] & $\begin{array}{l}\text { The performance of our IT infrastructure completely fulfils our business needs } \\
\text { regardless of usage magnitude. }\end{array}$ & 4.68 & 1.519 \\
\hline \multicolumn{2}{|c|}{$\begin{array}{l}\text { ITDCs } \\
\text { Please indicate how effective your company is in using IT systems for the following purposes: } \\
\text { (1-Not effective at all, 7-Highly effective) }\end{array}$} & & \\
\hline \multicolumn{2}{|l|}{ Sensing } & \multirow[b]{2}{*}{ Mean } & \multirow[b]{2}{*}{ S.D. } \\
\hline$\alpha=.86$ & $\mathrm{KMO}=.79$ & & \\
\hline [Sns 1] & \multirow{2}{*}{$\begin{array}{l}\text { Scanning the environment and identifying new business opportunities } \\
\text { Reviewing our product development efforts to ensure they are in line with what } \\
\text { the customers want. }\end{array}$} & 3.95 & 1.609 \\
\hline [Sns 2] & & 4.46 & 1.635 \\
\hline [Sns 3] & Implementing ideas for new products and improving existing products or services. & 4.60 & 1.573 \\
\hline [Sns 4] & $\begin{array}{l}\text { Anticipating discontinuities arising in our business domain by developing greater } \\
\text { reactive and proactive strength }\end{array}$ & 4.07 & 1.544 \\
\hline \multicolumn{2}{|c|}{ Integrating } & \multirow[b]{2}{*}{ Mean } & \multirow[b]{2}{*}{ S.D. } \\
\hline$\alpha=.89$ & $\mathrm{KMO}=.79$ & & \\
\hline [Int 1] & $\begin{array}{l}\text { Easily accessing data and other valuable resources in real time from business } \\
\text { partners }\end{array}$ & 4.44 & 1.621 \\
\hline [Int 2] & $\begin{array}{l}\text { Aggregating relevant information from business partners, suppliers and } \\
\text { customers. (e.g. operating information, business customer performance) }\end{array}$ & 4.25 & 1.695 \\
\hline [Int 3] & $\begin{array}{l}\text { Collaborating in demand forecasting and planning between our firm and our } \\
\text { business partners }\end{array}$ & 4.14 & 1.599 \\
\hline [Int 4] & Streamlining business processes with suppliers, distributors, and customers & 4.30 & 1.574 \\
\hline \multicolumn{2}{|c|}{ Coordinating } & \multirow[b]{2}{*}{ Mean } & \multirow[b]{2}{*}{ S.D. } \\
\hline$\alpha=.89$ & $\mathrm{KMO}=.83$ & & \\
\hline [Crd 1] & Providing more effective coordination among different functional activities & 4.41 & 1.463 \\
\hline [Crd 2] & $\begin{array}{l}\text { Providing more effective coordination with customers, business partners and } \\
\text { distributors }\end{array}$ & 4.52 & 1.363 \\
\hline [Crd 3] & $\begin{array}{l}\text { Ensuring that the output of work is synchronized with the work of other functional } \\
\text { units or business partners. }\end{array}$ & 4.40 & 1.443 \\
\hline [Crd 4] & $\begin{array}{l}\text { Reducing redundant tasks, or overlapping activities performed by different } \\
\text { operational units }\end{array}$ & 4.05 & 1.618 \\
\hline Reconfigu & & & \\
\hline$\alpha=.86$ & $\mathrm{KMO}=.79$ & Mean & S.D. \\
\hline [Rec 1] & Adjusting for and responding to unexpected changes easily & 4.14 & 1.543 \\
\hline [Rec 2] & $\begin{array}{l}\text { Easily adding an eligible new partner that you want to do business with, or } \\
\text { removing ones which you have terminated your partnership }\end{array}$ & 4.21 & 1.744 \\
\hline [Rec 3] & Adjusting our business processes in response to shifts in our business priorities & 3.98 & 1.472 \\
\hline [Rec 4] & $\begin{array}{l}\text { Reconfiguring our business processes in order to come up with new productive } \\
\text { assets }\end{array}$ & 3.96 & 1.477 \\
\hline Learning & & & \\
\hline$\alpha=.93$ & $\mathrm{KMO}=.85$ & Mean & S.D. \\
\hline [Lrn 1] & Identify, evaluate, and import new information and knowledge & 4.33 & 1.576 \\
\hline [Lrn 2] & Transform existing information into new knowledge & 4.33 & 1.534 \\
\hline [Lrn 3] & Assimilate new information and knowledge & 4.30 & 1.535 \\
\hline [Lrn 4] & Use accumulated information and knowledge to assist decision making & 4.25 & 1.495 \\
\hline $\begin{array}{l}\text { Innovatio } \\
\text { How woul } \\
\text { innovatior }\end{array}$ & $\begin{array}{l}\text { oupabilities } \\
\text { ou rate your organizations capability to generate the following types of } \\
n \text { the products/services you introduce (1-much weaker than competition; }\end{array}$ & & \\
\hline
\end{tabular}




\begin{tabular}{|c|c|c|c|c|}
\hline \multicolumn{3}{|c|}{ stronger than competition)? } & & \\
\hline \multicolumn{3}{|c|}{ Incremental innovations. } & \multirow[b]{2}{*}{ Mean } & \multirow[b]{2}{*}{ S.D. } \\
\hline$\alpha=.93$ & & $\mathrm{KMO}=.76$ & & \\
\hline [Inc 1] & \multicolumn{2}{|c|}{ Innovations that reinforce your prevailing product/service lines } & 4.59 & 1.206 \\
\hline [Inc 2] & \multicolumn{2}{|c|}{ Innovations that reinforce your existing expertise in prevailing products/services } & 4.70 & 1.144 \\
\hline [Inc 3] & \multicolumn{2}{|c|}{ Innovations that reinforce how you currently compete } & 4.56 & 1.172 \\
\hline \multicolumn{3}{|c|}{ Radical innovations } & \multirow[t]{2}{*}{ Mean } & \multirow[t]{2}{*}{ S.D. } \\
\hline$\alpha=.92$ & & $\mathrm{KMO}=.72$ & & \\
\hline [Rad 1] & \multicolumn{2}{|c|}{ Innovations that make your prevailing product/service lines obsolete } & 4.20 & 1.126 \\
\hline [Rad 2] & \multicolumn{2}{|c|}{ Innovations that fundamentally change your prevailing products/services } & 4.22 & 1.290 \\
\hline$[\operatorname{Rad} 3]$ & \multicolumn{2}{|c|}{$\begin{array}{l}\text { Innovations that make your existing expertise in prevailing products/services } \\
\text { obsolete }\end{array}$} & 4.20 & 1.164 \\
\hline \multicolumn{3}{|c|}{$\begin{array}{l}\text { Environmental complexity } \\
\text { With respect to the uncertainty of your environment, please indicate how much you agree or } \\
\text { disagree with the following statements (1-totally disagree, 7-totally agree) }\end{array}$} & & \\
\hline \multicolumn{3}{|c|}{$\begin{array}{l}\text { Environmental complexity } \\
\text { In our industry, there is considerable diversity in: }\end{array}$} & \multirow[b]{2}{*}{ Mean } & \multirow[b]{2}{*}{ S.D. } \\
\hline$\alpha=.78$ & & $\mathrm{KMO}=.69$ & & \\
\hline [Het 1] & \multicolumn{2}{|l|}{ Customer buying habits } & 4.00 & 1.751 \\
\hline [Het 2] & \multicolumn{2}{|l|}{ Nature of competition } & 3.86 & 1.777 \\
\hline [Het 3] & \multicolumn{2}{|l|}{ Product lines } & 4.07 & 1.766 \\
\hline
\end{tabular}

